Journal of Humanities, Social and Management Sciences (JHSMS)

eISSN: 2788-4791 (online)

https://doi.org/10.47264/idea.jhsms/1.1.2

Vol. 1, No. 1 (January-December 2020), 17-29

https:// www.ideapublishers.org/index.php/jhsms

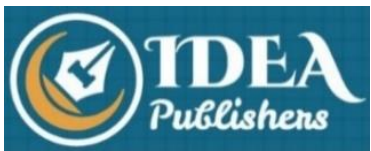

Research Article

\title{
Political Struggle for Women Empowerment: A Comparative Study of General Zia-ul-Haq and General Pervez Musharraf Era
}

\author{
Sobia Shabir*1 \& Amna Mahmood ${ }^{2}$
}

1. Department of History and Pakistan Studies, International Islamic University, Islamabad, Pakistan.

2. Department of Politics \& International Relations, International Islamic University, Islamabad, Pakistan

* Corresponding Author Email: sobiashabbir25@gmail.com

\begin{abstract}
Women are more than half of the Pakistan's population, still they are discriminated in every field of life due to prevailing misinterpreted religious teachings, patriarchy, and feudalistic values, which are deep rooted in society. Alongside, since independence military role remain dominant in political that have strong impact in shaping women status in Pakistan. For this reason, in this article comparison of two military regimes General Zia-ul-Haq and General Pervez Musharraf is made to explore how their policies shaped the women status in Pakistani society. General Zia was determined to Islamized the legal system of Pakistan, which limited the women within four walls of home; no practical political will was there to empower women. The introduction of Hadood Ordinance 1979, blocked women social, economic, and political liberation. Contrary to this, General Pervez Musharraf's era seems a cure, as political efforts made, for instance, Women Protection Bill 2006 introduced, and vague legislation introduced in General Zia era redrafted. First time in history of Pakistan women quota that much increased in National Assemblies of Pakistan, their political struggle to get rights encouraged, which resulted in women-oriented legislation. All this effort, remained very helpful to enhance the women social, economic, and political position at national level, and portrayed soft image of Pakistan internationally.
\end{abstract}

Keywords: Women Empowerment, Hadood Ordinance 1979, Women Protection Bill 2006, Zina Bill, Enlightened Modernization, Islamization Plan.

\section{How to Cite:}

Shabir, S. \& Mahmood, A. (2020). Political Struggle for Women Empowerment: A Comparative Study of General Zia-ul-Haq and General Pervez Musharraf Era. Journal of Humanities, Social and Management Sciences (JHSMS), 1(1), 17-29. https://doi.org/10.47264/idea.jhsms/1.1.2

\section{Publisher's Note:}

IDEA PUBLISHERS (IDEA Journals Group) stands neutral regarding jurisdictional claims in the published maps and institutional affiliations.

\section{Copyright:}

(C) 2020 The Author(s), published by IDEA PUBLISHERS (IDEA Journals Group)

This is an Open Access article published under the Creative Commons Attribution-NonCommercial 4.0 International License (http://creativecommons.org/licenses/by-nc/4.0/) 
Political Struggle for Women Empowerment: A Comparative Study of General Zia-ul-Haq ...

\section{Introduction}

Since independence, political system of Pakistan more or less has been in control of the military, encountering military take over from 1958-1971, 1977-1988 and 1999-2008. Weak democracy, religious, politics, nationalist movement, and controlled foreign policy, human rights violence specifically children, and women have been the character of Pakistan. Patriarchy is a dominant character in the culture of Pakistani society, where men action resides in the women action. They are supposed to serve men, don't have decision making power within, and outside of home. As, they are discouraged to go outside of home to get education, to communicate with opposite gender, and to play their role in professional life. Pakistani women don't have their own identity, they are being identified as someone's daughter, sister, mother, and wife. Their presences in the male dominated areas consider danger to the honour of male family members. In this scenario, despite of the fact that women are approximately more than half of the state population, political contribution of women, and their representation in administrative sectors, for instance, in government always remained a debatable issue.

In the present study political struggle for women empowerment during two out of four military regimes investigated. The first military regime is of General Zia-ul-Haq who tried to Islamized the state and society of Pakistan by trying to implement his slogan of Nizam-e-Mustafa. His government implemented such policies, which further highlighted the vulnerable position of Pakistani women. Since, women were already restricted within four walls of home, implementation of vague laws for instance, Zina law, Diyat and Qisaas law, law of evidence 1985 provide opportunities for male dominated society to more suppress, and exploit women in their own interests. The political status, and struggle for women empowerment in General Zia regime compared with other military regime that is of General Pervaz Musharraf. Unlike his counterpart Zia-ul-Haq, Musharraf had approach of 'Enlighted Modernization' a broadminded farsighted one keen to promote social consciousness in Pakistan. Women empowerment was a clear measure of General Pervez Musharraf moderate thoughts. The characteristics of General Pervez Musharraf period are exclusive and somewhat remarkable, as they were not at all observed earlier in the whole history of Pakistan. General Pervez Musharraf's period considered as the period of swift financial development, and Human Development in the state, and society of Pakistan. The political struggle for women empowerment was fruitful, women were encouraged to participate their role outside of the home, political participation of women increased, women were given ministerial positions in government, civil society actively promoted women-oriented values, the vague Hadood Ordinance 1979 replaced with the Women Protection Bill 2006. Since, the two military governments are entirely opposite to each other, therefore, best suited to compare the political struggle made to empower women in Pakistani state, and society.

\section{Literature Review}

The women participation in independence movements, and struggle for women political empowerment started right after independence of Pakistan. For this purpose, highly awarded and educated upper, upper middle class women from all the provinces remained extremely vigorous to take part in state politics. Accordingly, they fought political battle to carry out reforms to for the better socio-economic and political position of Pakistani women. This condition is examined by Khan (1995), right after the Pakistan appeared on the world map as an independent state, political power reserved in the hands of traditional feudal, therefore they 
began to marginalize the women from the public sphere particularly from the political involvement always discouraged. Consequently, the political position of women is weak like the social status of women in Pakistan. Actually women are not encouraged to participate in politics because of patriarchal socio-cultural settings, for example, old traditions, and customs alike Pakhtun Code of Conduct (Pakhtunwali). Women are discouraged to cast votes of their own choice, and kept away from politics. Although, Islamic teachings, and constitution of Pakistan encourage women to take part in politics, yet a robust opposition is there in society. So, women are never having sufficient representation in the national and provincial assemblies, and senate. Since Pakistan got independence female began their struggle enthusiastically to get due rights. For this purpose, the well-known women such as Begum Rana Liaquat Ali Khan assisted to refugees in providing basic needs. In 1948 a bill was presented in National Assembly to safeguard the economic rights of women albeit the bill was not approved, and women note down their anger by rallies.

The Constitution of 1956, also has given to cast vote for the reserved seats for women. It was women pressure that Rashid Commission 1951 formed to address women legal and social issues, and to bring changes in family laws, aim of the commission was to organize a survey in state about marriage, divorce, haq mehar, guardianship of children, and to have property rights for women. One more political effort made by the women in the history of Pakistan is the formation of 'The Muslim Family Laws Ordinance 1961', rendering to this law it is obligatory to register marriage, and divorce in the concerned Union Council. This law was appreciated by women in the state, then Muslim Personal Law Shariat Application Act 1962, approved; it carried out consistency about family laws all over Pakistan. An additional significant characteristic of this law was that it provided property rights to women. Family Courts Act 1964 was an optimistic step taken by the government for the protection rights of women (Socoroo, 2002; Critelli, 2010; Himan \& Kashif, 2017). Formerly, the period of Zulfiqar Ali Bhutto has been perceived as constructive and progressive for Pakistani women. As women were stimulated to contribute in national politics, first women Vice Chancellor employed, Begum Rana Liaquat Ali Khan was given the position of Governor of Sindh Assembly, all the government offices comprising foreign office opened for women jobs (Weiss, 2012). In the constitution of 1973 discrimination against women eradicated the then Prime Minister Zulfiqar Ali Bhutto formed 'Women land political position in Pakistan.

Aurat Foundation started to work in 1975 to improve women position in society. After that, the martial law administration of General Muhammad Zia-ul-Haq in Pakistan is approximately eight years old. He holds office on July 5, 1977, when Zia and his military companions remove from power to the government headed by Zulfiqar Ali Bhutto as Prime Minister of Pakistan. In lasting so long it has surpassed the normal life of military governments by a considerable extent (Chishti, 1989). Zia-ul-Haq government was an amalgamation of the mullah-military coalition where he utilized Islam to legalized his autocratic regime. The core factor of the Mullah-Military coalition was connected to the rule's prerequisite to mollify the right wing religious political groups to linger on in power. The exterior factor was associated to Soviet military existence in Afghanistan. Pakistan's military promoted the Jihadis to combat Pakistan's proxy war contrary to the former Soviet Union chastely to refute direct government involvement in the standoff. So, Islamization could have strong roots in the country due to the Zia-ul-Haq dogmas in Pakistan (Tahir, 1982). General Zia-ul-Haq, despite being an active and powerful president, was unsuccessful to develop an operative public policy. Not everybody was delighted with the execution of the Islamization package. General Zia-ul-Haq put stress on 
the existence and progress of Pakistan; yet, he believed Pakistan is an Islamic State, and not a Republic. He criticized secularism by not recognizing the significance of political course in bridging the gaps between competing interests of Muslims in Pakistan. Consequently, the gender policy of Pakistan obligatory to be included of both Islamic and Secular belief, but the over stress of General Zia-ul-Haq on Islamic part headed towards destructions in every facet, particularly, for the women progress in the patriarchal society of Pakistan (Saeed, 1997).

In November 1999, General Pervez Musharraf took charge of the government, by executing fourth Martial Law in the short history of Pakistan. General Pervez Musharraf had outwardly staged a coup d'état against elected Prime Minister who had betrayed Islamic Jihad in Kashmir, and uttered displeasure with Pakistan's pervious Taliban strategy. All the religious parties, controlled by Deobandi and their jihadi off shoots, had been rising to instigate an uprising against a pro-India and pro-Washington Prime Minister willing to block the economic channel that had made them sturdy and kept them going. To look unlike from the earlier military governments, General Pervez Musharraf announced himself 'Chief Executive' and not chief martial law administrator whereas appending simply parts of the constitution, and craftily circumventing imposition of martial law, however for all practical commitments his word was law. General Musharraf desired to endorse a liberal, liberal and a modest Pakistan at international level. The 'War on terror' provided him an excellent opportunity to get free of the radical elements. Entirely new position was taken in foreign policy; General Musharraf started to execute his principles internally. He worked for his vision of 'Enlightened Moderation'. This vision embraces the publicity of open-minded values, new education system, staging of soft image of Pakistan at international level, women political rights and development of technology and Electronic Media in the state.

\section{Theoretical Framework}

Pakistani society has multi-shaded culture; many researchers have defined and grasp cultural diversity of Pakistan in their own way. So, there is no cultural description that can be helpful to understand this diversity. For instance, Lyon an anthropologist (2002) has depicted Pakistan's geographical position as a motive of its cultural diversity. Despite this cultural diversity, there are certain cultural tools, customs, norms, belief, and values, which crate link among different sub-cultures into one entity of national culture (Shehab, 1989). According to the cultural dimensions described by the Geert Hofstede indigenous values of Pakistani culture can be categorized into three groups; stratification, collectivism, and gender segregation. Among these three cultural mechanism gender segregations is strongest in Pakistani values since stratification, and collectivism behaves according on the principle of gender segregation. Lyon and Greenfelder find out that gender segregation is a basic social norm of Pakistani society. Gender segregation is linked with the culturally defined manners is a centre means which discriminated places, times, tools, tasks, forms of speech, gestures, and view (Lyon, 2002; Hafeez, 1991; Khan, 1995).

Now with the understanding of this background, it is simple to know that the social status and roles of Pakistani individuals are determined on the principle of gender segregation. All through the socialization, process children are deliberately socialized conferring to the social norms of gender segregation. The gender roles are dominant in deciding daily routine in Pakistani society, and based on distinction between men, and women (Shaheed, 2010; Gazdar, 2008; Grunefelder, 2012). In Pakistani society, gender roles have two features: primarily, 
female is believed to be the subordinate of man and secondly, man's status/honour lies in the action of female family members. Therefore, respect and honour of the whole family stands on the modesty of a woman. So, to protect family honour and esteem social norms, and values are managed to regulate women conduct, movement, and dealings with opposite gender, physical space is mainly given to women in domestic as well as public spheres (Syed, Ali, \& Winstanley, 2005). Beside this, institution of purdah is utilized to control the free movement of women within, and outside of home. Since the 1970s, feminist movements increasingly talking about the rights of the women, this has strongly highlighted the position, and status of women in Pakistani society. Then, the onset of modern economy in Pakistan has gave new job openings for women, which forced to the existing politico-economic system to be changed, and have brought women into men space.

\section{Methods and Materials}

The study in hand is qualitative in nature, research utilizes explanatory, descriptive, and historical attitude as the problem is by tradition deep rooted. To gather data from primary and secondary sources utilized. For the collection of primary data Constitution of Pakistan 1973, Women Protection Bill 2006, Hadood Ordinance 1979 actualized. Beside secondary data was gathered through documents, newspapers, books, and academic articles. Research data gathered from primary and secondary sources examined by utilizing content analysis approach, which aids to present awareness about the issue in hand.

\section{Discussion and Findings}

From the given review of literature, it can be determined that General Zia's regime had given way to the prevalent problem in Pakistan which is the outcome of waned public policy, specifically legislation related to women empowerment. The faded women position in every field of life had been badly affected, and indeed the root cause of portraying bad image of Pakistan globally regarding human rights, particularly weak position of women. Although, General Musharraf government has been the only rule up to now, he challenged and encouraged political struggle for women empowerment. Afterwards, PPP, and PML administrations have always embraced some artifacts of General Zia's government which has carried out their collapse, however, they are not successful to understand that double approach of Islamization, and centralized power is surely not what the people of Pakistan desire to have.

\subsection{Women Political Rights during Regime of General Zia-ul-Haq (1977-1988)}

Pakistan is a patriarchal society where high status of women is considered as dishonour of men. Even in family women cannot enjoy the same and high position than of men, it is problem of male ego that's why women are ostracized in political power distribution. The feudal cultural values in the society are one more cause for the deprived condition of women. The feudal mentality has reinforced patriarchy in Pakistani state, and society. Consequently, discrimination within and outside of the home is a bitter experience for Pakistani women, and most of them are mandatory to modify in stated circumstances just to safeguard family integrity, and above to please male ego. For this reason, women suffer from violence, acid attacks, enforced marriages, leaving their property rights, and many more. Same condition in show up in a report of Amnesty International (2012), that Pakistani women situation is awful, and they are facing discrimination, and brutality. 
Political Struggle for Women Empowerment: A Comparative Study of General Zia-ul-Haq ...

General Muhammad Zia ul-Haq as chief of the army staff declared martial law in Pakistan, and made assured that martial law imposed to conduct free and fair election in the country within nineteen days. So, at first no ban levied on the activities of political parties, public was eyeing for free, and fair elections in national and provincial assemblies of Pakistan. Then, General Zia-ul-Haq cancelled elections and prohibited all kind activities of political parties, and began accountability of top political leaders. At the same time, General Zia-ul-Haq started his Islamization plan and launched Hadood Ordinance 1979, after one year he established Women Division as constituent of Cabinet Secretariat. He also started judicial reforms, initially religious scholars were in opposition to employ woman as a Qazi, afterwards in August 1982 Attorney General clarified that no such constraint found in Islam (Jalal, 1990).

General Zia-ul-Haq enthusiastically utilized his political power to craft legal system of Pakistan Islamic. In the first and second constitution of 1956, and 1962 correspondingly made Pakistan an Islamic Republic, but legal system kept secular in nature. After fall of Dhaka in 1971, a provision in the 1973 Constitution approved that all laws should be in according to Islam, still this article was not applicable in the courts. In 1979, General Zia introduced a chain of ordinances which meant to bring reforms in the legal system of Pakistan. Corresponding to this ordinance, drinking of alcohol, robbery, adultery, rape, and zina were overseen by Islamic Criminal Law. Prior to Hadood Ordinance Adultery, and fornication were not deemed as criminal action by law. The implementation of Hadood Ordinance cancelled all other sections of the Pakistan Penal Code, which earlier were watching over sexual crimes including rape, and alter them with its own apparently Islamic provisions. In case of violation of Ordinance rendering to the nature of the offense, the marital status of the offender, and the nature of the evidence. The action of adultery by a married person, for instance, if witnessed by four truthful Muslim males, might be punished by stoning till death. As commencement of Hadood Ordinance, it faced opposition by the secular part society, such as, civil society, and human rights activists. They directly criticized it, because it was ill written as many of its sections were not clear and ambiguous. This law gravely shaken the Pakistani women, who considered themselves more caged due to accusations of adultery, usually told by their husbands (Anita, 2021; Quraishi, 1999). Since, it was very easy to register case against a woman blame her of infidelity, while Zina Ordinance made it complex for women to obtain bail on undecided trial. The Zina Ordinance trapped women who had faced rape in an insecure legal trap, if they could not present eyewitnesses of rape they might be believed as offenders. In this condition, women were hesitant to register the rape cases (Talboot, 2009; Ziring, 2003). Zina is normally described by Islamic Law as illegal sexual interaction between a man and a woman who are not married to one each other. This contains extra-marital sex. The Zina law being a part of Hadood Ordinance, was condemned one, and obtained criticism from society, blasted by Pakistani press, it damaged international appearance of Pakistan.

It is told that in various cases, above 1500 rape sufferers were imprisoned, just because they could not provide male witnesses of their victimization. Consequently, victims were penalized, and their rapists were set free. This painful situation led human rights advocates to demonstrate against the Ordinance. In a case, 13-year-old blind rape victim, Safia Bibi reported her case against her boss, and his son for adultery, victim could not fulfil the condition of four male witnesses, and criminals were free. This ruling gained too much criticism from public, press highlighted the decision. Thus, the Federal Sharia Court reopened the case, decision of the case was reverted. This law didn't differentiate between adultery (zina-bil-raza), and rape (zina-biljabr). The sufferer of rape dealt, and penalzied as an offender, which discourage the victim to 
report the case instead, is protect to the rapist (Khan, 1999; Shahnaz, 2010; Saboor, 2014). Therefore, Zina laws indeed the whole Hadood Ordinances look to find and reinforce the belief of a 'pure and chaste' Pakistani national. In actual, these laws are different in Pakistani society, where male furious conduct towards female has no penalty in law, and the law enforcing bodies are full with corrupt persons.

The exploitation of women due to so called Islamization plan were convicted by all sections of the society. Thus, to stop the cruelty, and biasness against women, a forum 'Khawateen Mahaze- Amal was founded in 1981 by women supporters from elite class. This forum worked to take political action to watch over the legal rights of women. In 1983, General Zia-ul-Haq understood that development not possible by limiting women within four walls of home. So, special courts with female staff were proposed to deal with the cases of women, yet no practical action was taken (Rahat, 2005; Naima, 2013). 'Qanun-e-Shahadat' also known as Law of Evidence 1985, was another law which again targeted women position in Pakistani society. According to this law, woman's evidence was identified half that of a man by citing it as a religious ruling, as, many religious scholars recognized it as the misunderstanding of religious verdict. This law was critical not only because of woman's half testimony, yet it also discouraged rape sufferers to process complaints as they didn't have defined witnesses, which was the prerequisite of 'Law of Evidence'. The Law of Evidence 1885 was proposed by Islamic Ideology Council in 1982 to eliminate the 1872 Evidence Act, to eradicate the condition that two female witnesses are equal to two male witnesses (Human Rights Watch, 1999).

The Law of Qisas (justice) and Diyat (blood money) in Zia administration was a new controversial law which never can be decreed. Women Action Forum (WAF) rejected this law, eventually this law deferred time. The law was presented to various committees, but it could never pass. Under Islamization plan of General Zia Pakistani women confronted many hurdles to join state politics. Ansari Commission founded in 1983, this commission gave a report in which it was described that head of state must be Muslim male, age for members of Majlis-eShoora should be more than fifty, and women may be member only with the consent of their living husbands. Yet again, WAF spoked against these plans, and stated them un-Islamic, and biased. The WAF also opposed proposal of separate university for women. General Zia declared Islamic political agenda in 1985, amusingly he ignored the commission recommendation to limit political participation of women. In 1986, $9^{\text {th }}$ amendment was made in constitution, and specified that all laws should be according to the Quran, and Sunnah, Shariah bill approved which was again opposed by the WAF (Hassan, 1995). The period of General Zia has been most notorious about women rights in Pakistani state, and society. Being as, all the laws approved in his rule abridged women rights, and put them on lesser position. It damaged women contribution in social field; for example, female employments in foreign offices were void, dress code for women was also introduced, women at colleges, universities were restricted to veil themselves properly. The participation of women in politics was also opposed. In $1987 \mathrm{Zia}$ died in a plane crash in the surrounding area of Bahawalpur, with this a decade of his rule came to an end (Weiss, 1985; Rathore, 2015).

\subsection{General Pervez Musharraf and Political Struggle for Women Rights}

General Pervez Musharraf came into power by military coup in October 1999. His regime is seen as the enlightened after Zulfiqar Ali Bhutto about women rights. General Musharraf instigated his agenda 'Enlightened Modernization', and implemented actual plan to authorize 
women. According to his approach of 'Enlightened Modernization' he employed 07 women ministers in federal, and provincial cabinets. The influential ministries were assigned to women ministers, for example, women development, education, and law departments. Similar steps were taken in each military regime including General like Zia-ul-Haq to indulge the women in policies developing position by cheering involvement in local bodies' elections. Pakistani women progressed to noteworthy laws, for example, Muslim Family Laws Ordinance in the period of military leader General Muhammad Ayub Khan, though in 1979 another military leader General Zia abridged the women rights by introducing Hudood Ordinance 1979, and Law of Evidence 1985. Auspiciously, General Musharraf rule took actions to cure the upset position of women in Pakistan. The government of General Musharraf was devoted in improving the status, and position of women in state. His regime undertakes number of initiatives, and actions to free women from the grounds which caged them to accelerate their development (Yilmaz, 2016; Yilmaz \& Ahmed, 2018; Noreen \& Musarrat, 2014).

Table-1: Comparison of Women Representation in National Assembly, and Legislation for Women

\begin{tabular}{|c|c|c|c|}
\hline $\begin{array}{l}\text { Year \& } \\
\text { Leader }\end{array}$ & $\begin{array}{l}\text { Nature of } \\
\text { Government } \\
\& \quad \text { Political } \\
\text { leader }\end{array}$ & $\begin{array}{l}\text { Total Seats } \\
\text { for women in } \\
\text { National } \\
\text { Assembly }\end{array}$ & Gender Policies/Legislation \\
\hline $\begin{array}{l}\text { 1977-1985 } \\
\text { By General } \\
\text { Zia-ul-Haq }\end{array}$ & Military & $\begin{array}{l}10 \text { reserved } \\
\text { seats } \\
01 \text { woman } \\
\text { on general } \\
\text { seat (never } \\
\text { took oath due } \\
\text { to boycott of } \\
\text { opposition }\end{array}$ & $\begin{array}{ll}\checkmark & \text { Women's Division formed } \\
\checkmark & \text { Inquiry Commission on the Status of Women } \\
\checkmark & 2^{\text {nd }} \text { Women's Rights Commission established } \\
\checkmark & \text { Reserved seats doubled (20 in NA, previously it } \\
& \text { was } 10 \text { in NA) } \\
\checkmark & \text { Deptt. advanced to Ministry for Population } \\
\checkmark & \text { Welfare } \\
\checkmark & \text { Women Development Section included in Five }\end{array}$ \\
\hline $\begin{array}{l}\text { 1985-1988 } \\
\text { By General } \\
\text { Zia-ul-Haq }\end{array}$ & $\begin{array}{l}\text { Managed } \\
\text { democracy }\end{array}$ & $\begin{array}{l}20 \text { women on } \\
\text { reserved } \\
2 \text { on general } \\
\text { seats }\end{array}$ & 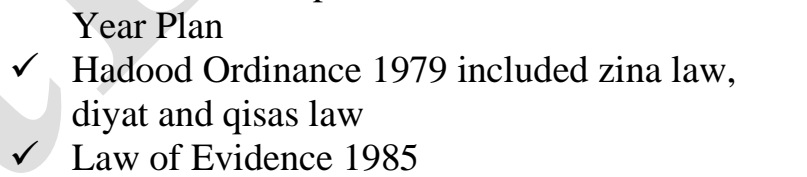 \\
\hline $\begin{array}{l}\text { By General } \\
\text { Pervez } \\
\text { Musharraf }\end{array}$ & $\begin{array}{l}\text { Military } \\
\text { Ruled by } \\
\text { General } \\
\text { Pervez } \\
\text { Musharraf } \\
(2000-2002) \\
\text { Managed } \\
\text { Democracy } \\
\text { by General } \\
\text { Pervez } \\
\text { Musharraf }\end{array}$ & $\begin{array}{l}74 \text { women on } \\
\text { reserved seats } \\
13 \text { on general } \\
\text { seats }\end{array}$ & $\begin{array}{ll}\checkmark & \text { Ordinances restored, and increased reserved } \\
& \text { seats quotas } \\
\checkmark & \text { National Commission on the Status of Women } \\
& \text { established } \\
\checkmark & \text { Citizenship Act amended } \\
\checkmark & \text { Family Courts Act amended } \\
\checkmark & \text { Nonparty Local government elections held } \\
\checkmark & \text { Honor Killing Act passed in } 2004 \\
\checkmark & \text { Women Protection Act } 2006 \\
\checkmark & \text { Laws approved to streamline bail for women } \\
\checkmark & \text { prisoners } \\
\checkmark & \text { Criminalization of customary laws }\end{array}$ \\
\hline
\end{tabular}

Source: Khan \& Naqvi, 2018

In 2000 General Pervez Musharraf founded National Commission on the status for women via presidential ordinance. The key purpose of the commission was to offer recommendations to foster the women position, and to carry out changes in the prevailing gender biased laws. Majority of the members were women, it was mandatory to add one member from all the provinces comprising tribal areas, and Azad Jammu Kashmir, and one member from minorities 
(Bibi \& Islam, 2018). Across the history of Pakistan, in 2002 parliament exhibited first time the maximum representation of women. In 2002, gender prejudiced laws were begun to change; many laws were the outcome of the misinterpretation of Islamic laws by religious scholars. Full efforts were put to depict a good image of Pakistan universally. For this purpose, series of legal modifications were introduced, for example, amendment in Citizenship Act 1951 instigated. Human Trafficking Ordinance 2000, was a part of Citizenship Act 1951, was changed the word 'father' and replaced with 'parent', illegitimate human trafficking was banned, child labour was forbidden. Honour killing was stated as murder, and ordered to all the law imposing bodies to treat this matter as an offence. The Criminal Law (Amendment Act, 2004), dealt with the laws like Qisas, and Diyat (Rai, 2007). Citizenship Act 1951 also amended, and Human Trafficking Ordinance 2000 approved and gender prejudiced words were swapped with neutral one. For instance, the word 'father' replaced with the 'parent'. For the prevention of women, child girls' smuggling, and forced labour a new ordinance passed in 2002 (Tabbasum, 2016). Honour killing seen as a murder, honour killing law passed in 2005, in which ordered to all concerned agencies to take all the actions to stop this act. One more initiative was taken, and the Prevention of Anti-Women Practices (Criminal Law Amendment) Bill 2006 sought to ban women abuse, forced marriages, and honour killing, and give them legal shelter 2004 (Knudsen, 2004; Muneer, 2018).

The Hadood Ordinance was changed with the Protection of Women Bill 2006 the development to redraft the Hudood Laws begun in June 2006 when Musharraf's regime called religious scholars to give proposals to review existing law about women rights. The Council of Islamic Ideology had proposed the government to revise the Hudood Laws in line of the Qur'an, Sunnah, and Sharia. Focus was to eliminate the zina bil jabr (adultery without agreement) law. Since this law mistreated Pakistani women, and made them weaker in the society. General Pervez Musharraf rule cheered women political contribution. For this purpose, regime involved women ministers in both the federal and provincial cabinets. Additionally, the control of important ministries was given to women such as women development, Education, ministry of law, and social welfare. The Women's Protection Bill of 2006, in Pakistan and all over in the world delighted. The army leader General Zia implemented the Hadood Ordinance, 1979, whereas the other military ruler General Pervez Musharraf substituted it and started bill opposing to previous. In 2006, Media highlighted the negative side of the Hadood Ordinance, and brought open minded religious scholars on television screen so that criticism on the Women Protection Bill 2006 may be discouraged. Irrevocably, bill passed from senate on $23^{\text {rd }}$ November 2006 (Year Book, Government of Pakistan, 2003-2004; Gazette of Pakistan Extraordinary, 2006).

General Musharraf sanctioned 'Devolution Plan 2001' it fortified political contribution of women, this program offered 33 percent women representation in local governments, for example, women got representation in town council, tehsil council, union council, and district council. Then in one Union Council of Punjab 20007 women elected, 6498 women elected in Sindh, in KPK (then NWFP) 3963 women elected, 2374 women elected in Baluchistan. In National Assembly women got representation of 21.6 percent, and it was 18 percent in Senate, though women had minimum quota, but this was a good step to raise their voices in the legislation regarding women. Furthermore, his rule was very much concerned to eliminate violence against women, this was needed because of the Universal Declaration of Human Rights and Convention on the Elimination of all kinds of Discrimination against Women (CEDAW) which has been backed by Pakistan government since 1996 and Beijing platform 
for action (Awan\& Muhammad, 2018). General Musharraf designed National Policy 2002 to give power to women, and to eradicate biased attitudes towards women in Pakistan. His regime initiated family courts to deal the cases of violence against women. For the first time in the history of Pakistan, under military regime, in 2000, the quota for women's political participation was elevated to $33 \%$ at the local government level. This quota was valid at three levels of the local government, particularly the union council, the tehsil 9 and the district level. Similarly, before 2002 election, the quota of women was increased to $17 \%$ alike the national and provincial assemblies (with 61 out of 342 members in the national assembly being women). A notable rise in the quota also improved women's general contribution in the political system for the election of 2002. In the election of 2002, 188 women in total contested general seats, and of these 188, 101 were selected by political parties, and 39 amongst them won their corresponding seats. To compare this to the 1997 election, this ratio was near approximately 1/3: just 56 women contested the election, amongst them 39 were chosen by political parties, and only 7 succeeded (Khattak, 2010; Khan \& Naqvi, 2020).

\section{Conclusion}

Throughout the political history in Pakistan, Islam is remained a factor to obtain favour of public. The same tactic was used by General Zia-ul-Haq to extend his regime, his Islamization programme provide place to the dogmatism, and fundamentalism in Pakistani state and society. Because of various motives General Zia-ul-Haq's rule and his polices continued as a theme even in current discussions. The careful examination of the current study depicts that regime of General Zia favoured to the gender discriminated legislation and it was supported by cultural values and political system rather than religion. For this purpose, Islamic teachings on the status of women in family, and society was misinterpreted. Since, when one studies the Islam it is very clear that Islam is the only religion in the world to speak out regarding the rights of weak segments of the society particularly women and children. There is no room in Islam about the discrimination of women, but rather Islam has given the rights, and esteemed status to women. Women not just has right to have own private property, but she also has right to sell and buy it. Yet religious scholars are isolating women from society by implementing double standards; due to this delusion of religious philosophies. General Zia's gender discriminatory legislation made problems not merely for the women in the accomplishment of their daily duties, but also blocked them to participate in socio-economic and political development. These actions stimulated traditionalist of the society to exploit the women. Moreover, his plans received disrespect about the status and position of women in Pakistan at global level, and for that reason General Musharraf government got extreme pressure from international community. So, general Musharraf was forced to make laws to safeguard women rights so that they can perform their duties in public life.

Contrary to General Zia, General Musharraf wisely adopted an opposed approach of 'Enlightened Modernization' thus General Musharraf regime was considered as a cure to the General Zia's gender prejudiced legislation. His government seems a solution for women due to his gender flexible legislation, women proportion in national, and provincial assemblies increased, and they were handed over ministries which useful to improve the women status at national level, and portrayed a soft image of Pakistan internationally. General Musharraf was compelled to do so more vigorously after $9 / 11$ event when international community was looking Pakistan as a state who is abusing human rights particularly women rights received more attention. Thus, General Musharraf was a liberal-minded military leader keen to indorse 
social awareness in Pakistan. Women liberation was a self-evident step of General Musharraf liberal thinking. He intended Pakistan among the fastest rising countries of the world for which he struggled to formulate faultless policies for every sector. It was his trust that for the rebirth of Pakistan from ashes to gold, it should become a secular state, free from all sorts of biases. Few adversaries claimed that General Musharraf was a dictator minded person, as he assumed the same track of referendum like General Zia to extend his regime. In fact, he was the first dictator who permitted all political parties to take part in the elections, and he favoured women empowerment by increasing women quota in assemblies.

\section{References}

Anita M. W. (2012). Moving Forward with the Legal Empowerment of Women in Pakistan, (United States Institutes of Peace, 2012).

Awan, A. \& Muhammad, A. (2018). Political Participation of Women in Pakistan; Historical and Political Dynamics Shaping the Structure of Politics for Women. Frankfurter Forschungszentrum Global Islam.

Bibi, H. \& Islam, F. (2018). Causes of Meager Participation of Women Parliamentarian in Khyber Pakhtunkhawa Assembly; and the Way Out. Central Asia Journal 84(Summer), $125-136$. centralasia.edu.pk/index.php/ca/article/view/24

http://www.asc-

Critelli, M.F. (2010). Women's Rights Human Rights: Pakistani Women against Gender Violence. Western Michigan University: The Journal of Sociology and Social Welfare. $37 \quad$ (2), 135-160. https://heinonline.org/HOL/LandingPage?handle=hein.journals/jrlsasw37\&div=20\& id=\&page $=$

Fiaz, A.C. (1989). Betrayals of another Kind: Islam, Democracy and the Army in Pakistan. Rawalpindi, PCL Publishing House.

Gazdar, H. (2008). No Longer Worried about Becoming a 'Free Sex Zone'. Economic and Political Weekly, 8-9.

Gazette of Pakistan Extraordinary, Protection of Women. (2006). Criminal Laws Amendment Act.

Grunenfelder, J. (2012). Gender, Work and Development in Northwest Pakistan: Working Environments of Pakistani Female Development Practitioners. Originally Published at: University of Zurich, Faculty of Science. https://www.zora.uzh.ch/id/eprint/63450/1/Gruenenfelder2012_gesamt.pdf.

Hassan, Y. (1995). The Heaven Becomes Hell: A Study of Domestic Violence in Pakistan. Lahore Cantt, Pakistan: Shirkat Gah, WLUML Coordination Office Asia.

Himan, H., \& Kashif, A. (2017). Empirical Investigation of Organizational Culture, Societal and Personality Barriers of Female Employees to Become Leaders in Pakistan. International Journal of Innovative Knowledge Concepts, 5 (8).

Human Rights Watch. (1999). Custom or Crime? Violence against Women in Pakistan. New York: Oxford University Press.

Jalal, A. (1990). The State of Martial Rule: The Origins of Pakistan's Political Economy. Cambridge South Asian Studies, 323-324.

Khan A. (2007). "Pathways of Women's Empowerment South Asia Research Programme Pakistan Scoping Paper". Dhaka: University Press Ltd.

Khan, A. Naqvi, S. (2020). Dilemmas of Representation: Women in Pakistan's Assemblies. Asian Affairs. 
Political Struggle for Women Empowerment: A Comparative Study of General Zia-ul-Haq ...

Khan, R. (2009). Situational Analysis and Mapping of Women's Human Rights in Pakistan. CIDA Pakistan Program.

Khan, S. (1995). Pakistan: Past, Present and Future. Lahore: Aalameen Publication Press.

Khan, N., \& Naqvi, S. (2018). Women in Politics: Gaining Ground for Progressive Outcomes in Pakistan. Institute for Development Studies.

Khattak, G. S. (2010). Women in Local Government: The Pakistan Experience. Institute of Development Studies.

Kirmani, N. (2000). Women's Rights as Human Rights: The Case of Pakistan. University of Tennessee, Knoxville.

Knudsen, J.A. (2004). License to Kill: Honour Killing in Pakistan. Chr. Michelson Institute Development Studies and Human Rights.

Lyon, S. (2002). Power and Patronage in Pakistan, Unpublished PhD Dissertation, University of Kent, Canterbury.

Muneer, S. (2018). Pro-Women Laws in Pakistan: Challenges towards Implementation. Pakistan Vision, 18(2), 86-101. http://pu.edu.pk/images/journal/studies/PDFFILES/Article-5_v18_2_Dec17.pdf

Naima, S. (2013). Women's Political Participation and the Laws to Protect Women in Pakistan. Pakistan Journal of Women's Studies: Alam-e-Niswan, 20 (2), 99-115.

Noreen, N. Musarrat, R. (2014). Women "e Struggle for Legal Empowerment in Pakistan Historical Overview. Journal of Public Administration and Governance, 4(1), 134166. https://doi/10.5296/jpag.v4i1.5460

Quraishi, A. (1999). Her Honor: An Islamic Critique of the Rape Laws of Pakistan from a Woman-Sensitive Perspective. Islamic Studies, 38:3.

Rahat, I. (2005). Legal Injustices: The Zina Hadood Ordinance of Pakistan and Its Implications for women. Journal of International Women's Studies, 7(2), 78-100.

Rai, M. S. (2007). Achieving Gender Equality in Public Offices in Pakistan. United Nations Development Programs in Pakistan.

Rathore, A. M. (2015). Women's Rights in Pakistan: The Zina Ordinance and Need to Reform. School pf Public Policy.

Saboor, R. (2014). Rape Laws in Pakistan: Will we Learn from our Mistakes? Islamabad L. Review, 1 , $65 . \quad$ https://www.iiu.edu.pk/wpcontent/uploads/downloads/journals/ilr/volume1/num-

1/Article_4_Vol1_1_010817.pdf

Saeed, S. (1997). Civil-Military Relations in Pakistan, from Zulfiqar Ali Bhutto to Benazir Bhutto. Pakistan: Westview.

Shaheed, F. (2010). Contested Identities: Gendered Politics, Gendered Religion in Pakistan. Third World Quarterly, 31, 6, 851-67.

Shahnaz, K. (2010). Locating the Feminist Voice: The Debate on the Zina Ordinance. Pakistani Women: Multiple Locations and Competing Narratives. Karachi: Oxford University Press, 147.

Shehab, R. (1989). History of Pakistan. Lahore: Sang-e-Meel Publications.

Socoroo, L.R. (2002). Quotas for Women Legislative Seats at the Local Level in Pakistan. Stockholm: International Idea.

Syed, J., F. Ali \& D. Winstanley. (2005). In Pursuit of Modesty: Contextual Emotional Labour and the Dilemma for Working Women in Islamic Societies. International Journal of Work Organization and Emotion, 1 (2). 150-167. ISSN 1740-8938.

Tabassum, N. (2016). Women in Pakistan: Status in Socio-Cultural and Politico-Legal Domains. Sindh Jamshoroo: Area Study Centre. 
Tahir, A. (1982). Afghanistan Crisis: Implications and Options for Muslim World, Iran and Pakistan. Institute of Policy Study.

Talboot, I. (2009). Pakistan: A Modern History. Hurst.

Weiss, M.A. (1985). Women's Position in Pakistan: Sociocultural Effects of Islamization. University of California, 25(8). 863-880. https://doi.org/10.2307/2644115

Weiss, M. A. (2012). Moving Forward with the Legal Empowerment of Women in Pakistan.

Year Book. (2003-2004). Global Vision Publishing House, New Delhi, Government of Pakistan, Ministry of Women Development.

Yilmaz, I. (2016). Muslim Laws, Politics and Society in Modern Nation States: Dynamic Legal Pluralism in Iran, Turkey, and Pakistan. Kindle Edition, Routledge.

Yilmaz, I. \& Ahmed, S. Z. (2018). Islam and Women Rights in Pakistan, SSRN Electronic Journal. https://dx.doi.org/10.2139/ssrn.3229025

Ziring, L. (2003). Pakistan at the Cross-Current of History. England: One World Oxford. 